\title{
Study on the Economic Law of Macroscopical Control \\ Zongkai Yang
}

Tianjin University, Tianjin, 300072

\section{Keywords: Macroscopical Control, Economic Law, Society Development}

\begin{abstract}
With the establishment and development of Chinese socialist market economic system, it has played a great role in the development of Chinese national economy and the improvement of people's living standard, which fully proves the scientificity and validity of the system model. However, in the actual operation, the market may appear blind and out of control phenomenon, for the good operation of the economy caused considerable negative impact \# This requires the state through effective macro-control policies to make up for the lack of market economy, through the invisible hand to achieve Economic environment optimization and promotion of economic law as a market economy to achieve its legal economic goals an important guarantee, fully understand its position in the macro-control and role in order to ensure that the macro-control policy of the legal system for Chinese economic sustainable development solid foundation.
\end{abstract}

\section{Introduction}

The government's macroeconomic regulation and control behavior refers to the government from the overall interests of the national economy to stabilize prices, promote full employment, maintain moderate economic growth, to achieve balance of payments as the goal, from the development of economic behavior norms, in varying degrees to economic planning, The industrial policy to guide the use of financial, monetary, credit, sanctions and other economic, legal and necessary administrative means, from the overall regulation of the national economy to run the economic management behavior. In essence, the government's macro-control behavior is a strict economic management behavior, is the basic form of modern state intervention in the economy, but also the highest form of economic management behavior, is relative to the economic management of the specific economic management behavior of. Its value lies in the government through a series of control means, so that macroeconomic activities through market intermediaries and market microeconomic activities of the organic combination of the total supply and demand to maintain the basic balance, emphasizing the whole society's public interest first. In this sense, the protection of the individual interests of the market is placed in a secondary position.

\section{Research on the Concept of Government Regulation}

Macroeconomic regulation and control behavior and ordinary economic management behavior compared to its wide range of specificity. It is the government standing in the public interest of the whole society from the perspective of the overall operation of the national economy to regulate and control, highlighting the central state administrative organs of the economic functions. Our policy is new. Unlike in the past, it is between laissez-faire capitalism and welfare the third road between the state, the essence of which refers to the government from the macroeconomic regulation and control of the economic operation. Second, it is manifested in its generalization of macro-control behavior in addition to large-scale investment projects and market access Approval and licensing, and many other macroeconomic regulation and control behavior, including the development of market economic behavior norms, the preparation of economic development plans, adjust interest rates, exchange rates, tax rates, to take financial, investment, credit and other measures are from a comprehensive, for a certain range All of the relative people, rather than for some or a few specific counterparts, that is, all the relative people are binding, and these measures once the implementation of the publication has a strong public power .. so the government's macro-control behavior Posed new challenges to our previous division of economic management, since most macroeconomic 
controls are not abstract administrative Although the majority of the objects of their conduct are not specific or universal in most cases, most of them are not acts of normative and universally applicable normative documents, but are not ordinary economic management practices. Of the specific economic management behavior is characterized by the management of the behavior of the object of the specific and specific. In fact, the government's macro-control behavior is a general economic management behavior, that is, specific matters on the implementation of non-specific counterparts in economic management Third, the creation of the government's macro-control behavior in most cases is based on the international and domestic economic development needs of the flexible, in the process, the main macro-control is not strictly based on the existing laws and regulations, and According to the changes in the situation need to immediately release policies, orders and regulations, rules and regulations to regulate the market economy behavior; put forward economic development plans and industrial policies and preferential measures to guide the operation of the market economy; by exercising administrative discretion at any time to adjust interest rates, Tax rates, exchange rates, wages, money, credit scale, strong market Sexual regulation, and constantly summed up the new rules, etc. All of these have a strong creativity, not just in accordance with the existing laws and regulations of the provisions of the mechanical implementation. Throughout the East and West countries to implement macro the economic background of regulation and control is carried out in order to save, restore and revitalize the national economy in times of emergency economic situation, unstable economic order, even in emergencies such as suffering or facing economic crisis and war damage.

\section{Macro-Control Behavior Caused by the Legal Relationship}

Macroeconomic management is generally considered the function of the central government. ',. In general, the main body of macro-control behavior is a central economic management of the country, with high-level, professional. In the United States, its economic management institutions and organizations engaged in macroeconomic regulation and control include: the White House Office, the Administration and Budget Bureau, the Economic Advisory Committee, the Policy Development Office, the Ministry of Commerce, the Ministry of Finance and so on; Germany is engaged in the national macro- The organization includes: the Federal Ministry of Economic Affairs, the Ministry of Finance, the Ministry of Economic Cooperation, the Federal Economic Information Administration, the Federal Bank, etc., there are a large number of consulting and research institutions; Japan's large province, the Ministry of International Trade and Industry, the Ministry of Agriculture and Fisheries, Economic Planning Office Institutions and organizations are also mainly engaged in macro-control. The Chinese macroeconomic regulation and control of the economic management is organs or control of the main body, including the People's Bank of China, the Ministry of Finance, the State Development Planning Commission, the State Economic and Trade Commission and the Ministry of Foreign Trade and so on. It can be seen that the main body of macroeconomic regulation and control is mainly the central administrative body and organization engaged in the core economic affairs of economic planning, finance and taxation, currency, domestic and foreign trade and business administration. Ordinary economic management departments play a supporting role in the national macroeconomic regulation and control. The governing body or organization plays a major role in the implementation of the central macro-control policies, measures and decisions.

In most cases, the counterparty of macroeconomic regulation and control behavior is not specific or numerous. This is different from the ordinary economic and legal relations, the general economic and legal relations generally have the economic management and counterparty counterparts. The relative party is a specific specific citizen, legal person or other organization. Thus, we can say that macro-control behavior generally refers to the macro-control subject to macro-control transactions on the implementation of non-specific counterparts with a macro, general of economic management behavior. Such as government control of currency issuance, the implementation of foreign exchange control, tax rate, exchange rate, interest rate adjustment, promotion or control of import and export trade, government investment, government bidding and market access, etc. belong to specific 
economic management behavior, but mainly for non-specific The majority of people to implement, so can not simply apply the traditional or existing economic management behavior of the classification criteria for macro-control behavior classification.

The strategic characteristics of macroscopical control legal relations are thicker. In the modern market economy conditions, as the government's macro-control behavior counterparts of the citizens, legal persons are self-management, self-financing, self-restraint, self-development of the market, a wide range of independent management decision-making, coupled with macro-control behavior itself Is for the majority of the relative to the people, so the economic management agencies to develop economic planning, industrial policy guidance, consumer guidance and investment guidance and other macro-control behavior must be translated into a specific citizen, legal person's conscious will, that only in the specific Legal and administrative assistance, the general economic management behavior is the burden of economic management organs unilateral will and administrative enforcement of the backing to achieve its objectives.

\section{The Role of Economic Law in Macroscopical Control System}

With the deepening of global economic integration, the economic ties between countries are getting closer and closer. Such as a country's economic problems, other countries will also be a greater impact and implicated. How to realize the effective control of risk is an important subject in the current national economic development. The development and perfection of economic law can effectively monitor the state's macroeconomy, such as the precursor of the crisis, under the supervision of economic law, can effectively eliminate the potential problems in the economy, the crisis block, Chinese economic security, to avoid a serious economic crisis. From the global financial crisis and the impact of Chinese economic situation, it is the role of economic regulation under the macro-control to play its huge role.

Although the market economy on the national economic development has a huge role in promoting and promoting, but its own drawbacks can not be ignored. In the course of the operation of the market economy, there are some businesses to maximize their own interests, and to take unfair competition means, and through jerry-building and opportunistic behavior to obtain the best interests, resulting in huge losses of consumers and the market order of the great damage. Under the influence of economic law, the state can use the macro-control policy, with the powerful tool of economic law, the market of illegal and disciplinary businessmen to severely punish, to crack down on illegal acts to protect the interests of consumers and ensure the normal operation of Chinese macroeconomic The

China is a socialist country, in the realization of political development and economic development, but also pay attention to the legal system construction and development. The construction of the socialist legal system is the inevitable direction of Chinese future development, but also to achieve with the world, to ensure that Chinese economic environment and a good political environment to build an important guarantee. As an important part of the legal system, the construction and perfection of economic law is an important aspect that must be completed, and it is also an important force to promote the construction of our socialist legal system. The construction of the socialist legal system has also created a favorable environment for the standardized implementation of Chinese macro-control policies and provided important guarantee for the stability of Chinese macro economy.

Economic law is in the national macro-control in the important position and role, to promote the improvement of its legal system to become Chinese future development of one of the important work. In order to give full play to its great role in macroeconomic regulation and control and market economy development, we should first improve and supplement the current economic law, make up for the loopholes in the existing problems, make the economic legislation system more comprehensive and three-dimensional to give full play to its The Reference Function of Economic Judicial Act. At the same time, we should realize the establishment and perfection of the economic and judicial institutions at all levels in our country and improve the quality of law enforcement personnel. When the state needs to implement the macroscopical control policies, we can make full 
use of economic and legal system, in the strict economic law enforcement procedures, to achieve Chinese economic stability and sustainable development.

\section{Conclusion}

Economic law plays an important role in Chinese national macro-control, and plays an important role in the implementation of macro-control behavior. With the continuous progress of Chinese socialist market economic system construction, economic law in the future national economic development and macro-control in the unique role will be further highlighted.

\section{References}

[1] Xing Huiqiang. Macroeconomic regulation and control behavior can not be prosecuted legal and economic interpretation [J]. Economic Law Research, 2013 (10)

[2] Hao Yan. Study on the theory of actionability of macro-control behavior [J]. China Foreign Investment, 2011 (16)

[3] Huang Ganglan. Reflection and Reconstruction of Legalization of Macro-control Behavior [J] .Journal of Shanxi Normal University, 2010 (S1)

[4] Li Zhi. The role of economic law in the development of market economy [J]. Chinese and foreign entrepreneurs, 2015 (26)

[5] Huang Maoqin. The new economic background under the comprehensive development of economic law [J]. Journal of Nanhua University, 2015 (04)

[6] Zhang Zheng. The relationship between economic law and state intervention [J]. Journal of Southwest Petroleum University, 2014 (01) 